\title{
ANALISIS KESULITAN SISWA TERHADAP POKOK BAHASAN PANGKAT RASIONAL DAN BENTUK AKAR DI KELAS X SMA BINA DHARMA 2 BANDUNG
}

\author{
Vevi Hermawan', Andrianto ${ }^{2}$ \\ ${ }^{1}$ Universitas Pasundan \\ vevi_pmat@unpas.ac.id
}

\begin{abstract}
ABSTRAK
Pada pembelajaran pokok bahasan pangkat rasional dan bentuk akar, siswa dituntut untuk mengingat kembali pelajaran saat di SLTP seperti tentang bilangan berpangkat dengan bilangan pokok 10, pengertian perpangkatan, bilangan pokok, dan pangkat. Kesulitan siswa dalam mempelajari pokok bahasan tersebut lebih banyak disebabkan siswa lupa akan sifat-sifat bilangan tersebut. Tujuan dari penelitian adalah untuk mengetahui letak kesulitan siswa kelas 1 SMU Bina Dharma 2 Bandung dalam pembelajaran pokok bahasan pangkat rasional dan bentuk akar. Sebagai subyek penelitian ini adalah siswa kelas I SMU Bina Dharma 2 Bandung. Setelah dipilih secara acak maka diperoleh kelas I-1 sebagai subyek penelitiannya. Metode penelitian yang digunakan metode deskriptif dan sebagai instrumen yang digunakan dalam penelitian ini adalah tes. Hasil dari penelitian ini adalah pada sub pokok bahasan pangkat bulat positif dan negatif, siswa mengalami kesulitan menggunakan sifat-sifatnya, pada sub pokok bahasan bentuk akar siswa mengalami kesulitan dalam mengubah bentuk akar menjadi bilangan berpangkat, pada sub pokok bahasan merasionalkan bentuk akar siswa mengalami kesulitan dalam menentukan bentuk sekawan dari penyebut pecahan tersebut, dan pada sub pokok bahasan persamaan pangkat sederhana siswa mengalami kesulitan dalam mengubah suatu bilangan menjadi bilangan berpangkat
\end{abstract}

Kata Kunci: kesulitan siswa, pangkat rasional dan akar

\begin{abstract}
In learning the subject of rational rank and root form, students are required to recall lessons at SLTP such as numbered numbers with a base number of 10, understanding of ranks, principal numbers, and powers. Students' difficulties in basic matters are more than what happens to students forget about the characteristics of these numbers. The purpose of the study was to study the location of the difficulties of grade 1 students of Bina Dharma 2 High School in Bandung in learning the subject of rational rank and root form. As the subject of this study were first-grade students of Bina Dharma 2 High School Bandung. After being randomly selected, I-1 class was obtained as the subject of his research. The research method used the descriptive method and the instrument used in this study is a test. The results of this study are on the subject of positive and negative rounded ranks, students overcome difficulties using their properties, in the subject of student root form difficulties in changing the shape of roots into numbers, on the subject rationalize the form of students' roots of difficulty the denominator of the fraction, and in the subject matter of the simple equation the student overcomes the difficulty in changing numbers to rank numbers.
\end{abstract}

Keywords: student difficulties, rational rank, and roots. 


\section{PENDAHULUAN}

Pendidikan Nasional bertujuan mencerdaskan kehidupan bangsa dan mengembangkan manusia Indonesia seutuhnya, yaitu manusia yang beriman dan bertakwa terhadap Tuhan Yang Maha Esa dan berbudi pekerti luhur, memiliki pengetahuan dan keterampilan, kesehatan jasmani dan rohani, berkepribadian yang mantap dan mandiri serta rasa tanggung jawab kemasyarakatan dan kebangsaan (Pasal 4 UU Nomor 2 Tahun 1989). Untuk mewujudkan hal tersebut dibutuhkan suatu sistem pendidikan yang solid sehingga dapat menciptakan manusia yang berpengetahuan tinggi dan berguna bagi nusa dan bangsa.

Dengan sistem pendidikan yang baik diharapkan muncul generasi penerus bangsa yang berkualitas dan mampu menyesuaikan diri untuk hidup bermasyarakat, berbangsa dan bernegara. The Director General of Teachers and Education Personnel (GTK) reported that based on the results of Teacher Competency Test (UKG) administered at the end of 2015, the average scores was 53.02. The competencies tested are professional competence and pedagogic competency. Based on the data, it is still necessary to improve the quality of teachers in Indonesia, Darta \& Saputra (2018: 2).

Matematika merupakan kumpulan ide atau konsep abstrak yang tersusun secara hierarkis, maksudnya antara materi yang satu dengan materi yang lain saling berkaitan atau masih ada hubungan dengan yang lain. Seringkali banyak siswa yang kurang menguasai suatu materi mendapat kesulitan bila diberi materi baru yang masih ada keterkaitan dengan materi yang baru. Hudoyo (1990: 5) menyatakan bahwa, "Untuk mempelajari materi matematika maka pengalaman belajar yang lalu akan mempengaruhi terjadinya proses belajar materi matematika tersebut".

Pembelajaran Matematika lebih berorientasi pada pemahaman konsep, penemuan dan penerepan pada kehidupan sehari-hari. Pada pembelajaran matematika, guru berperan penting dalam menyampaikan materi pada siswanya. Jadi bila siswa tidak mengerti tentang apa yang diterangkan oleh gurunya, yang juga dapat disalahkan selain sisa itu sendiri adalah guru. Hal tersebut dapat terjadi dikarenakan guru tersebut dalam menyampaikan materi terhadap siswa terlalu cepat sehingga siswa sulit menangkap apa yang disampaikan (diterangkan) atau guru kurang memberikan contoh soal maupun soal-soal latihan.

Pada pembelajaran pokok bahasan pangkat rasional dan bentuk akar, siswa dituntut untuk mengingat kembali pelajaran saat SLTP seperti tentang bilangan berpangkat dengan bilangan pokok 10, pengertian perpangkatan, bilangan pokok, dan pangkat. Konsep tersebut dapat membantu untuk memahami pengertian pangkat rasional dan bentuk akar. 
Dalam pokok bahasan ini memang kelihatanya sangat mudah dan sederhana bagi siswa tetapi bila diberikan soal latihan yang berbeda dengan contoh soal yang diberikan pada saat proses belajar mengajar, seringkali siswa masih mendapat kesulitan.

Pembelajaran pokok bahasan pangkat rasioal dan bentuk akar tersebut pada setiap sub pokok bahasan terdapat sifat-sifat atau teorema-teorema yang satu dan yang lainnya saling mendukung. Karena banyak sifat-sifat atau teorema-teorema yang satu dan yang lainnya saling mendukung, dan karena banyak sifat-sifat pada pokok bahasan tersebut banyak siswa yang tidak hafal dan lupa, sehingga bila diberikan soal-soal yang jawabannya membutuhkan sifat-sifat tersebut tetapi siswa tersebut tidak bisa menggunakan sifat-sifat tersebut, sehingga bila menjawab soal-soal latihan jawabannya asal-asalan atau serampangan tidak sesusai dengan kosep yang diberikan.

Hal ini sesuai dengan apa yang dinyatakan oleh Ruseffendi (1991: 134), bahwa "banyak anak-anak yang telah belajar matematika yang sederhana pun banyak yang dipahami secara keliru, matematika dianggap sebagai ilmu yang ruwet, dan sukar". Pendapat lain dikemukakan oleh Aprilla (Nurhayati, 2003: 2), "Penyebab minat siswa untuk belajar matematika itu rendah adalah karena tidak menariknya pembelajaran matematika dan materinya sukar". Hal ini disebabkan karena pembelajaran matematika selama ini kurang menyenangkan, padahal proses pembelajaran yang menyenangkan dapat dijadikan sebagai suatu hiburan, dan bukan lagi menjadi hal yang menakutkan bagi siswa. Sehingga kemasan pembelajaran yang menarik pastilah akan mendapat perhatian yang serius dari para siswa, Saputra (2013: 219).

Imbasnya adalah hal-hal tersebut yang menjadikan siswa mengalami kesulitan dalam mengikuti pembelajaran matematika. Kesulitan-kesulitan tersebut dapat meyebabkan ketidaksukaan siswa terhadap matematika, yang dapat berimbas kepada nilai tes matematika siswa. Untuk mencari tahu dimana letak kesulitan atau kelemahan siswa dalam pelajaran matematika yaitu dengan mengadakan evaluasi. Dengan evaluasi tesebut kita dapat menganalisa di mana letak kesulitan-kesulitan yang dihadapi siswa dalam mempelajari pokok bahasan pangkat rasional dan bentuk akar. Salah satu acuannya adalah apa yang diungkap oleh Reys, dkk (1984. Dalam Ruseffendi, 1992: 28), bahwa "matematika merupakan telaah tentang pola dan hubungan, suatu jalan atau pola berfikir, suatu seni, suatu bahasa dan suatu alat". Hal tersebut sesuai pendapat Saputra (2015: 78),” Pembelajaran yang berdayaguna atau berpusat pada masalah digerakkan oleh keinginan bawaan peserta didik untuk menyelidiki secara pribadi situasinya". 
Berdasarkan hal tersebut masalah yang akan penulis teliti yaitu di mana letak kesulitan siswa kelas 1 SMU Bina Dharma 2 Bandung dalam pembelajaran pokok bahasan pangkat rasional dan bentuk akar.

\section{METODE PENELITIAN}

Penelitian ini dilaksanakan di SMU Bina Dharma 2 Bandung. Untuk subyek dalam penelitian ini adalah siswa kelas 1 SMU Bina Dharma 2 Bandung. Banyaknya subyek dalam penelitian ini adalah 310 orang, yang terdiri dari 135 orang siswa laki-laki dan 175 orang siswa perempuan, seluruhnya tersebar dalam 7 (tujuh) kelas yaitu I-1 hingga I-7 dengan perbandingan yang relatif sama. Karena subyek dalam penelitian ini tersebar dalam 7 kelas dan mengingat karakteristik dari kelas yang satu dengan kelas yang lainnya relatif sama, maka dalam penelitian ini penulis mengambil satu kelas sebagai sampel dengan tidak membentuk kelas baru. Dengan dipilih secara acak maka diperoleh kelas I-1 yang jumlah siswanya adalah 42 orang sebagai kelas sampel. Kelas I-1 terdiri dari 18 orang siswa laki-laki dan 24 orang siswa perempuan. Untuk mengumpulkan data pada penelitian ini yaitu dengan mengadakan tes. Pada penelitian ini metode yang digunakan adalah metode deskriptif dan instrumen yang digunakan adalah tes.

Pada tahap tindakan dan observasi, penulis melakasanakan kegiatan belajar mengajar dengan membahas pokok bahasan pangkat rasional dan bentuk akar. Untuk pelaksanaan kegiatan belajar mengajar pada pokok bahasan pangkat rasional dan bentuk akar, penulis mengalokasikan waktu 12 jam pelajaran ditambah 2 jam pelajaran. Pelaksanaan kegiatan belajar mengajar dilakukan dalam 6 kali pertemuan. Setiap pertemuan menggunakan 2 jam pelajaran. Untuk mengetahui sampai dimana pemahaman siswa terhadap apa yang telah diajarkan oleh penulis, maka setiap akhir pertemuan diadakan tes.

\section{HASIL DAN PEMBAHASAN}

Berdasaran hasil postes dari setiap pertemuan diperoleh data letak kesulitan siswa dalam pembelajaran pokok bahwasan pangkat rasional dan bentuk akar, maka didapat hasil dengan yaitu, pada sub pokok bahasan pangkat bulat positif, 20\% siswa mengalami kesulitan dalam menggunakan sifat-sifat pangkat bulat positif. Pada soal pangkat bulat positif yang merupakan perpaduan dua buah sifat pada pangkat bulat positif, siswa sering bingung menentukan sifat mana yang dipergunakan. 


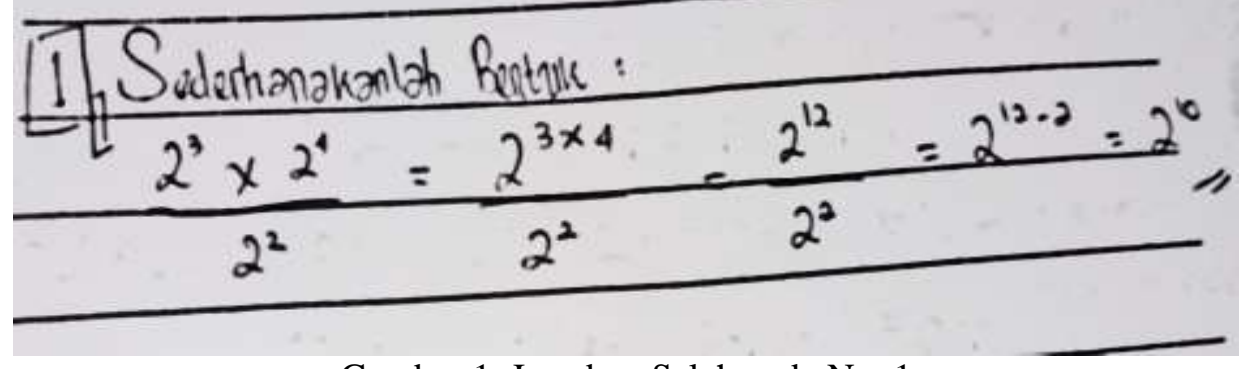

Gambar 1. Jawaban Salah pada No. 1

Jawaban yang benar adalah $\frac{2^{3} \times 2^{4}}{2^{2}}=\frac{2^{3+4}}{2^{2}}=\frac{2^{7}}{2^{2}}=2^{7-2}=2^{5}$.Pada sub pokok bahasan pangkat bulat negatif, 20\% siswa pada umumnya mengalami kesulitan dalam menjumlahkan atau mengurangkan pangkat dari suatu bilangan berpangkat dengan pangkat bulat negatif. Mereka sering bingung menjumlahkan atau mengurangkan bilangan yang bernilai negatif dengan positif maupun dengan bernilai negatif lagi.

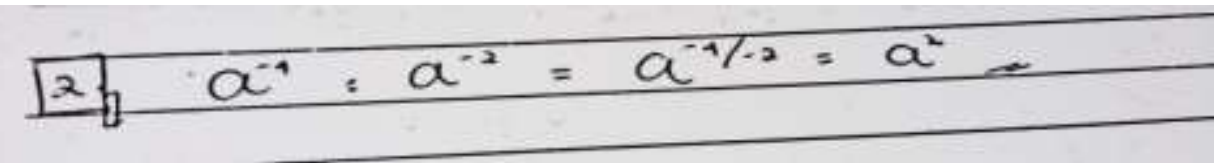

Gambar 2. Jawaban Salah pada No. 2

Jawaban yang benar adalah $a^{-4}: a^{-2}=a^{-4-(-2)}=a^{-2}$. Pada sub pokok bahasan bentuk akar, 20\% siswa mendapat kesulitan dalam mengubah suatu bentuk akar menjadi suatu bilangan berpangkat suatu pecahan, menjumlahkan, mengurangkan, dan mengalikan bentuk akar. Pada menjumlahkan danmengurangkan bentuk akar sering kali siswa tidak teliti dalam menjumlahkan dan mengurangkannya. Bentuk akar bisa dijumlahkan dan dikurangi hanya jika suku-sukunya memuat bentuk akar yang sejenis dan yang dijumlahka serta dikurangi adalah koefisiennya. Seringkali siswa menjumlahkan atau mengurangkan bentuk akar yang suku-sukunya memuat bentuk yang berbeda.

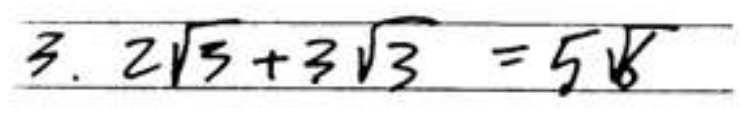

Gambar 3. Jawaban Salah pada No. 3

Jawaban yang benar adalah $2 \sqrt{3}+3 \sqrt{3}=(2+3) \sqrt{3}=5 \sqrt{3}$. Untuk sub pokok bahasan merasionalkan penyebut sebuah pecahan berbentuk $\frac{a}{\sqrt{b}}$. $50 \%$ siswa mendapatkan kesulitan dalam mengalikan pembilang dan penyebut yang seharusnya dikalikan dengan penyebutnya sendiri sering dikalikan dengan pembilangnya. 


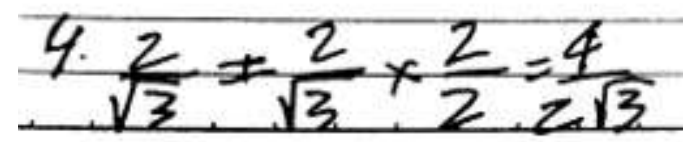

Gambar 4. Jawaban Salah pada No. 4

Jawaban yang benar adalah $\frac{2}{\sqrt{3}}=\frac{2}{\sqrt{3}} \times \frac{\sqrt{3}}{\sqrt{3}}=\frac{2 \sqrt{3}}{3}=\frac{2}{3} \sqrt{3}$. Untuk sub pokok bahasan merasionalkan suatu penyebut suatu pecahan bentuk $\frac{c}{a \pm \sqrt{b}}$. Pada umumnya $50 \%$ kesalahan siswa terletak dalam menentukan pengali untuk pembilang dan penyebutnya. Banyak siswa yang mengalikan pembilang dan penyebut untuk merasionalkan penyebut pecahan tersbut dengan mengalikannya dengan pembilangnya. Ada juga siswa yang mengalikan dengan penyebutnya bukan bentuk sekawannya dari penyebut pecahan tersebut.

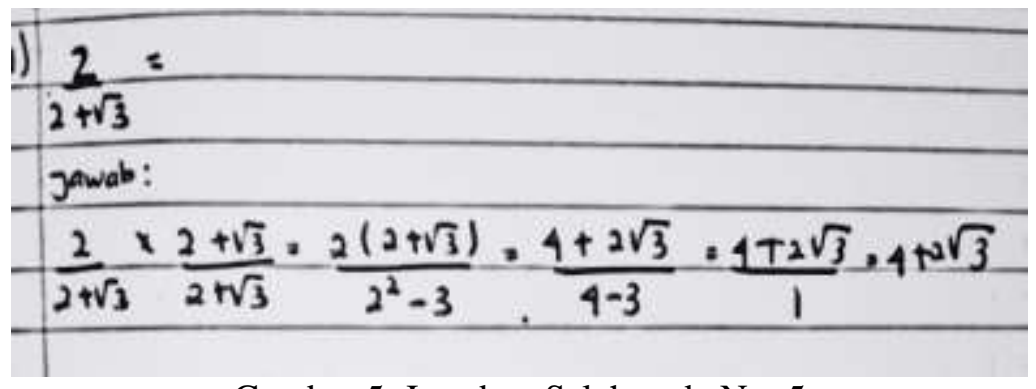

Gambar 5. Jawaban Salah pada No. 5

Jawaban tersebut adalah salah, karena pembilang dan penyebut dikalikan bukan dengan bentuk sekawan dari penyebut pecahan tersebut. Seharusnya pembilang dan penyebut dikalikan dengan bentuk sekawan dari penyebunya yaitu $2-\sqrt{3}$. Jawaban yang benar adalah $\frac{2}{2+\sqrt{3}}=\frac{2}{2+\sqrt{3}} \times \frac{2-\sqrt{3}}{2-\sqrt{3}}=\frac{2(2-\sqrt{3})}{2^{2}-3}=\frac{4-2 \sqrt{3}}{4-3}=\frac{4-2 \sqrt{3}}{1}=4-2 \sqrt{3}$

Merasionalkan penyebut pecahan dalam bentuk $\frac{c}{\sqrt{a}+\sqrt{b}}$. Dalam merasionalkan penyebut $\frac{c}{\sqrt{a}+\sqrt{b}}, 50 \%$ siswa kesulitan dalam menentukan pengali untuk pembilang dengan penyebut pecahan tersebut. Sama dengan bentuk yang sebelumnya dibahas sering siswa mengalikan pembilang dan penyebut pecahan tersebut bukan dengan bentuk sekawan dari penyebutnya.

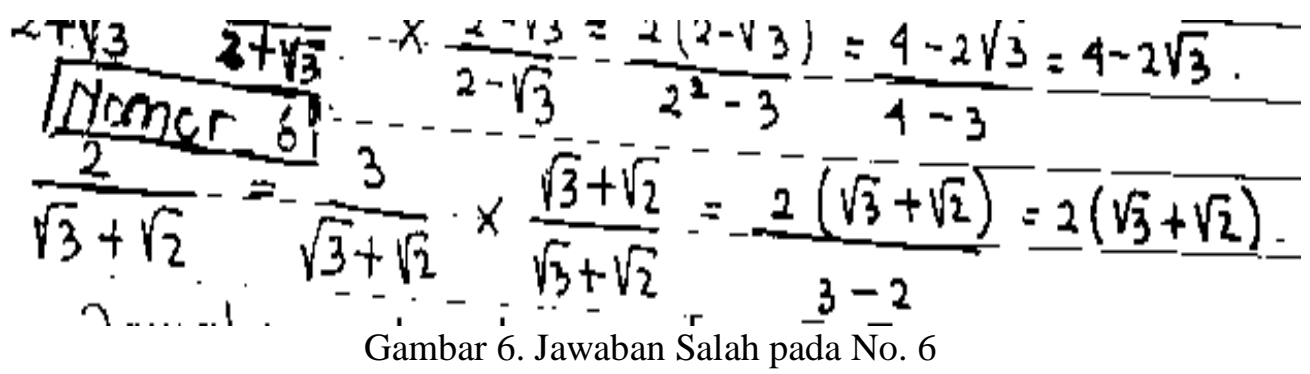


Dari contoh tersebut jawabannya adalah salah karena pembilang dan penyebut dikalikan dengan penyebut pecahan sendiri. Seharusnya pembilang dan penyebut dikalian dengan bentuk sekawan dari penyebutnya yaitu $\sqrt{3}-\sqrt{2}$. Sehingga jawaban yang benar adalah $\frac{2}{\sqrt{3}+\sqrt{2}}=\frac{2}{\sqrt{3}+\sqrt{2}} \times \frac{\sqrt{3}-\sqrt{2}}{\sqrt{3}-\sqrt{2}}=\frac{2(\sqrt{3}-\sqrt{2})}{3-2}=2(\sqrt{3}-\sqrt{2})$. Merasionalkan penyebut bilangan berbentuk $\frac{c}{\sqrt{a}-\sqrt{b}}, 40 \%$ siswa dalam merasionalkan bentuk pecahan $\frac{c}{\sqrt{a}-\sqrt{b}}$ sama dengan bentuk sebelumnya. Letak kesalahannya pada pengali dari pembilang dan penyebut pecahan tersebut.

Menyelesaikan persamaan pangkat sederhana. Pada sub pokok bahasan tersebut $20 \%$ siswa menjdapat kesulitan dalam mengubah suatu bilangan menjadi suatu bilangan berpangkat dalam suatu persaman pangkat sederhana, seperti berikut $4^{\mathrm{x}+2}=64$. Siswa sering kesulitan dalam mengubah angka 64 menjadi suatubilangan berpangkat.

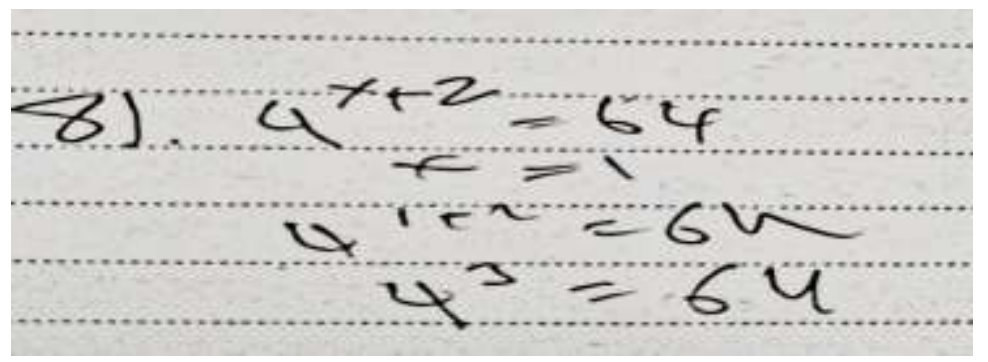

Gambar 7. Jawaban Proses Keliru pada No. 5

Matematika merupakan telaah tentang pola dan hubungan, suatu jalan atau pola berfikir, suatu seni, suatu bahasa dan suatu alat. (Reys, 1984. Dalam Ruseffendi, 1992: 28). Dari pernyataan tersebut serta dikaitkan dengan jawaban siswa, terlihat bahwa siswa kesulitan untuk mencari suatu pola serta keterhubungan konsep pada pokok bahasan pangkat rasioanal dan bentuk akar, sehingga para siswa memilih kecenderungan menebak atau menduga, dan hal tersebut pun mereka tetap mengalami kesulitan.

Selanjutnya akan dilakukan penelitian lanjutan untuk mengukur komunikasi dan dampaknya terhadap self-regulated learning dengan bantuan teknologi, karena selfregulated learning of high-ranked and low-ranked students who obtain a maple program is better than the self- regulated learning of high-ranked and low-ranked students who expository learning, Saputra (2017a). Oleh karena itu diperlukna analisis juga untuk melihat hubungan antara self-regulated learning dan komunikasinya. Terlebih dahulu siswa harus diberi kesempatan berkomunikasi secara tervuka dan mandiri, karena selfregulated learning peserta didik bisa dicapai jika dalam proses pembelajaran memberi kesempatan terbuka bagi mahasiswa untuk belajar secara mandiri, Saputra (2017b: 117). 


\section{KESIMPULAN}

Sebagai kesimpulan, penulis menyimpulkan bahwa pada dasarnya kesulitan yang dialami oleh para siswa sebagian besar adalah pada langkah awal (proses) penyelesaian soal. Mereka seperti tidak tahu harus mulai dari mana dan akan berakhir di mana. Sangat riskan jika hal tersebut tidak segera dibenahi dari awal oleh para guru, karena hal tersebut, pertama akan menjadi kebiasaan siswa dan tidak menutup kemungkinan akan menjadi karakter siswa itu sendiri. Kedua, kesulitan ini akan semakin kompleks mengingat jenjang yang akan mereka lalui akan semakin tinggi, dimana membutuhkan kompetensi yang mumpuni dalam melewati proses tiap jenjangnya.

\section{REFERENSI}

Darta \& Saputra, J. (2018). Indicators that Influence Prospective Mathematics Teachers Representational and Reasoning Abilities. Journal of Physics: Conference Series 948 (1), 012053. DOI :10.1088/1742-6596/948/1/012053.

DEPDIKBUD. (1993).Kurikulum Sekolah Menengah Umum. Jakarta: DEPDIKBUD

DEPDIKBUD. (1995). Kurikulum Sekolah Menengah Umum dan GBPP Mata Pelajaran Matematika. Jakarta : DEPDIKBUD

Hudoyo, Herman. (1990). Mengajar Belajar Matematika. Jakarta: P2LPTK.

Nurhayati. (2003). Upaya Meningkatkan Motivasi Siswa pada Pembelajaran Matematika Dengan Menggunakan Alat Peraga. Skripsi. Tidak dipublikasikan. Bandung: Universitas Pasundan.

Republik Indonesia. 1989. Undang-Undang No. 2 Tahun 1989 tentang Sistem Pendidikan Nasional. Sekretariat Kabinet RI. Jakarta.

Ruseffendi, E. T. (1991). Pengantar kepada Membantu Guru Mengembangkan Kopetensinya dalam Pengajaran Matematika untuk Meningkatkan CBSA. Bandung: Tarsito.

Ruseffendi, E.T. (1992). Pendidikan Matematika 3. Jakarta: Depdikbud.

Saputra, J. (2013). Pengaruh Model Pembelajaran Edutainment dengan Pendekatan Somatic, Auditory, Visualization, And Intelectually (SAVI) terhadap Kemampuan Komunikasi Matematis Siswa SMA. SYMMETRY: Jurnal Pendidikan Matematika, 4 (1), 217-226.

Saputra, J. (2015). Penggunaan Model Problem Based Learning Berbantuan E-Learning Dalam Upaya Meningkatkan Kemampuan Pemecahan Masalah Matematis dan Dampaknya terhadap Kemandirian Belajar Mahasiswa. Pasundan Journal of Mathematics Eduation Jurnal Pendidikan Matematika, 5 (2), 77-87.

Saputra, J. (2017a). The application of the Maple Program to Self-Regulated Learning on The Mathematics' Prospective Teachers Students. International Conference: Character Building Through Pricesly International Education Series 1 (1).

Saputra, J. (2017b). Penggunaan Model Problem Based Learning Berbantuan E-Learning Terhadap Kemandirian Belajar Mahasiswa pada Dimensi Tiga. KALAMATIKA \begin{tabular}{lllll}
\hline Jurnal Pendidikan & Matematika, & 2 & (2),
\end{tabular} DOI: http://dx.doi.org/10.22236/KALAMATIKA.vol2no2.2017pp117-130

Syah, Muhibbin. (1995). Psikologi Pendidikan. Bandung: Remaja Rosda Karya.

Syamsudin, Abin. (1995). Psikologi Pendidikan Suatu Pendekatan Baru. Bandung: Remaja Rosda Karya. 
Tampomas, Husein. (1999). Seribu Pena Matematika SMU Kelas 1. Jakarta: Erlangga. Winatapura, S. Udin (1994). Belajar dan Pembelajaran. Jakarta: DEPDIKBUD.

Wirodikromo, Sartono. (1995). Matematika untuk Kelas 1 Caturwulan 1. Jakarta: Erlangga. 